\title{
PRAKTIK YOGA ARSITEK BADE: \\ MEMBACA PRAKTIK YOGA PENGLUKUNAN DASA AKSARA UNDAGI BADE
}

\author{
Oleh \\ I Putu Gede Suyoga \\ Sekolah Tinggi Desain Bali Denpasar
}

Email: pgsuyoga@gmail.com

\begin{abstract}
Every profession has the realm of yoga applications that are relevant to the practice of their profession. An undagi "architect" in addition to equipping himself with design skills and technical skills for "artifacts", is also obliged to master the mind (yoga), one of which is the literacy technique "union of ten scripts / holy letters". This study aims to uncover the phenomenon of undagi bade which is able to capture the knowledge behind the script as a practice of yoga for spiritual practice, and manifested in the form of bade architectural artifacts. This study is a qualitative study with a descriptive analytical approach. Collecting data by observation and documentation. Determination of informants is done by purposive sampling. Data analysis was based on Michel Foucault's knowledge power relations theory. The results of the study showed that the architecture of the bade was composed of pepalihan (parts) that compose parts of the body and roof. The shape varies there are those who are not overlapping called a container and whose roof is overlapped is called a bade, some even have no roof (open) called padma. This roof variant is the result of a deep contemplation of "yoga" literacy. Knowledge of the dasa aksukan capturing was captured by undagi bade to be developed as power in the practice of his profession. This power of knowledge practice applies in the realm of Balinese society whose bodies have been disciplined, obedient and useful in carrying out ceremonial cultural practices of death. Personally the meaning of yoga in literacy is the practice of training the undagi self-discipline in seeking authenticity on the path of Tantra.
\end{abstract}

Keywords: yoga, dasa aksara, undagi bade, bade architecture

\section{ABSTRAK}

Setiap profesi memiliki ranah aplikasi yoga yang relevan dengan praktik profesinya. Seorang undagi 'arsitek' disamping membekali dirinya dengan keahlian desain dan ketrampilan teknis untuk olah fisik "artefak", juga wajib menguasai olah bathin "yoga", salah satunya teknik penglukunan dasa aksara 'penyatuan sepuluh bija aksara/huruf suci'. Studi ini bertujuan mengungkap fenomana undagi bade yang mampu menangkap pengetahuan dibalik dasa aksara sebagai praktik yoga untuk olah bathin, dan diwujudkan dalam bentuk artefak arsitektur bade. Studi ini merupakan penelitian kualitatif dengan pendekatan deskriptif analitis. Pengumpulan data dengan observasi dan dokumentasi. Penentuan informan dilakukan dengan purposive sampling. Analisis data dilandasi teori relasi kuasa pengetahuan Michel Foucault. Hasil penelitian menunjukkan arsitektur bade tersusun atas pepalihan (bagian-bagian) yang menyusun bagian badan dan atapnya. Bentuknya bervariasi ada yang tidak bertumpang disebut wadah dan yang atapnya bertumpang disebut bade, bahkan ada yang tidak beratap (terbuka) disebut padma. Varian atap ini merupakan hasil kontemplasi mendalam "yoga" penglukunan dasa aksara. Pengetahuan tentang penglukunan dasa aksara ditangkap oleh undagi bade untuk dikembangkan sebagai kuasa dalam praktik profesinya. Praktik kuasa pengetahuan ini berlaku di ranah masyarakat Bali yang tubuhnya telah disiplin, patuh dan berguna dalam menjalankan praktik kultural seremonial kematian. Secara personal makna yoga penglukunan dasa aksara menjadi praktik pelatihan disiplin diri sang undagi dalam mencari kesejatian di jalan Tantra.

Kata kunci: yoga, dasa aksara, undagi bade, arsitektur bade 


\section{PENDAHULUAN}

Praktik ritus kematian merupakan hal penting dan mendasar dalam relasi sosio-religius masyarakat manusia yang sudah berlangsung sejak era purba. Masyarakat prasejarah Bali misalnya, dengan segala kesederhanaan peradabannya telah memiliki cara perawatan jenasah, yang dibuktikan dengan penemuan arkeolog berupa teknik kubur batu, kubur tempayan terakota, sarkopagus, dan yang lainnya.

Perkembangan kebudayaan Bali yang telah dilandasi kepercayaan kepada roh suci leluhur yang tinggal di puncak-puncak bukit dan gunung, berangsur-angsur dipermulia dengan konsepsi dalam ajaran Hindu. Ritual dan teknik ritus kematian pun berkembang, tidak saja dengan penguburan namun juga dengan dikremasi. Kedua ritual kematian ini pasti dilengkapi dengan bangunan pengusung jenasah dari bentuknya yang sangat sederhana sampai yang bentuknya rumit. Bentuk ini terinspirasi dari bentuk gunung sebagai transformasi puncak gunung Maliawan.

Bentuk arsitektural bangunan pengusung jenasahpun kemudian dirancang mengikuti aturan stratifikasi sosial tradisional yang berkembang berlandaskan ajaran keagamaan Hindu. Konsepkonsep dalam ajaran teologi Hindu yang berkembang pesat di era Bali Pertengahan atau era Bali Majapahit (1343 M) semakin mewarnai keanekaragaman bentukan arsitektural bangunan kematian. Ketatnya hirarkhi kemasyarakatan era kerajaan ini, mewujud dalam bentuk varian bangunan pengusung jenasah mendiang. Bentuknya disesuaikan dengan perbedaan profesi, jabatan di lingkup kerajaan, kepemimpinan di tengah masyarakat desa, dan jasa baik yang pernah dilakukan, atau bahkan sebaliknya, prilaku yang dianggap sebagai penghianatan kepada kerajaan. Bangunan kematian kemudian dibedakan berdasarkan bentuknya, seperti pepaga, joli, bebaturan/lelimasan, wadah, bade, dan bade dengan nagabanda.
Bangunan pengusung jenasah atau disebut arsitektur bade merupakan istilah baru yang ditawarkan untuk merujuk salah satu bentuk bangunan pengantar jenasah menuju keburan atau tempat kremasi dalam praktik seremonial kematian masyarakat Bali. Seorang ahli bangunan "arsitek tradisional Bali" perancang karya arsitektur bade tersebut, secara tradisional dikenal dengan sebutan undagi bade atau undagi wadah.

Seorang undagi bade memiliki tanggungjawab besar dalam menerjemahkan konsepsi yang sudah tertulis dalam lontar terkait panduan membangun arsitektur bade. Panduan rancang bangun tersebut dibuat berdasarkan hasil kontemplasi mendalam "yoga" sang kawi sastra yang juga seorang undagi. Salah satu hasil internalisasi konsep yoga yang berhasil ditransformasikan ke dalam konsep pengembangan rancang bangun arsitektur bade, adalah penglukunan dasa aksara 'penyatuan sepuluh aksara suci'. Posisi dan perputaran aksara suci di makrokosmik di yuj-kan dengan posisi dan perputarannya di mikrokosmik tubuh undagi. Hal ini merupakan sebuah kuasa pengetahuan dalam pemikiran Foucault yang menarik digali proses pembentukannya.

Di samping itu, secara aplikatif luasnya kekuasaan seorang mendiang semasa hidupnya, yang akan memakai sebuah bentuk wadah/bade tertentu, juga merupakan sebuah pengetahuan yang harus dipertimbangkan undagi bade. Hal menariknya adalah bagaimana pengetahuan di balik dasa aksara itu ditangkap oleh undagi bade, kemudian dipaduserasikan dengan luasnya kekuasaan (dalam arti harfiah) mendiang, untuk dijadikan kuasa dalam disain rancang bangun wadah/bade yang akan dipakai mendiang dan keturunannya kelak dikemudian hari.

Foucault memahami, setiap pengetahuan mengandung kuasa, kekuasaan menghasilkan pengetahuan, dalam arti tidak ada kekuasaan tanpa pengetahuan (Haryatmoko, 2016: 17), dengan demikian akan semakin menarik dikaji proses pemaknaan sebuah artefak 'benda budaya' yang 
dipakai dalam ritus kematian masyarakat Bali tersebut. Guna memudahkan, maka akan dimulai dari ontologinya, yakni dari wujud fisiknya yang terlihat.

Arsitektur bade merupakan hasil karya undagi bade yang dapat dipahami dalam wujud fisiknya yang sekala 'riil' berupa karya arsitektural sarat simbolik, dan secara niskala 'idiil' dalam bentuk olah bathin sebagai pendakian spiritual seorang undagi. Proses pemaknaan inilah menjadi satu fenomena menarik yang perlu diungkap utamanya terkait dengan pemahaman praktik yoga dalam praktik kultural masyarakat Bali tersebut.

Variasi bentukbangunankematianmenyimpan sejumlah pengetahuan. Apa pengetahuan dan kuasa di balik dasa aksara itu? Bagaimana pengetahuan itu ditangkap oleh aktor-aktor intelektual organik untuk dijadikan kuasa dalam mengembangkan wacana bangunan kematian? kemudian juga menarik digali proses pendisiplinan tubuh-tubuh umat Hindu untuk senantiasa patuh dan berguna dalam praktik kultural ritus kematian tersebut, apakah karena kuatnya relasi kuasa pengetahuan tersebut? Sejumlah pertanyaan tersebut dapat dirumuskan sebagai pertanyaan penelitian sebagai berikut: (1) Bagaimana relasi kuasa pengetahuan yoga penglukunan dasa aksara bertransformasi menjadi arsitektur bade? (2) Bagaimana kuasa pengetahuan dibalik yoga penglukunan dasa aksara ditangkap dan dimaknai oleh undagi bade?

Studi ini bertujuan mengungkap fenomena laku yoga seorang undagi bade yang mampu menangkap pengetahuan dibalik dasa aksara sebagai teknik yoga untuk praktik olah bathin dan diwujudkan dalam bentuk artefak arsitektur wadah/bade. Studi ini merupakan penelitian kualitatif dengan pendekatan deskriftif analitis. Pengumpulan data dengan observasi dan dokumentasi. Penentuan informan dilakukan dengan purposive sampling. Guna memudahkan pemahaman dan proses analisis sejumlah referensi transliterasi lontar juga dipergunakan seperti: Lontar Dasa Aksara, Lontar Indik Mekarya Bade,
Lontar Asta Kosalaning Wong Pejah, dan Lontar Asta Kosala Kosali. Selanjutnya analisis data dilandasi teori relasi kuasa pengetahuan Michel Foucault, dan juga pengembangan teori relasi kuasa pengetahuan tersebut ke kuasa wacana, maupun kuasa disiplin.

\section{PEMBAHASAN}

\subsection{Pengertian Dasa Aksara sebagai Praktik Yoga}

Dasa Aksara merupakan sebuah jalan Tantra yang salah satu tujuan utamanya adalah peningkatkan kesadaran ilahi, dengan merenungi keilahian semua elemen alam semesta dan keterhubungannya dengan diri sendiri. Praktik Tantra bertujuan melebarkan kesadaran, atau dengan kata lain membuat peningkatan kesadaran, bukan hanya dewa di tempat suci yang sakral yang memiliki getaran spiritual, namun semua mahluk dan semua tempat di alam semesta, termasuk semua organ dalam diri serta semua fungsi psikologis, merupakan elemen yang sakral dan memiliki getaran spiritual, yang mana getaran spiritual di dalam diri (bhuana alit) dan di alam semesta (bhuana agung) sejatinya adalah sama dan satu.

Yudiantara (2016: 207), menyatakan dalam ajaran Dasa Aksara semua aksara hanacaraka yang jumlahnya 20 akan disarikan dalam 10 aksara, lalu sepuluh aksara tersebut tersarikan lagi menjadi panca brahma (sa, ba, ta, a, i), kemudian tersarikan menjadi triaksara, yaitu ang, ung, dan mang, menjadi dwiaksara (ang, ah) dan kemudian menunggal menjadi Ongkara. Dasa Aksara merupakan wija mantra yang terselip dan menjadi bagian tidak terpisahkan dari mantra-mantra dan puja-puja doa orang Bali, baik untuk kepentingan yadnya atau untuk kepentingan-kepentingan lain yang lebih spesifik (pengiwa 'ilmu kiri', penengen 'ilmu kanan', pengusadhan 'pengobatan', dan lain sebagainya).

Setiap aksara suci tersebut memiliki tempatnya masing-masing di bhuana agung 
(di sembilan arah mata angin, plus di tengah), memiliki dewa penguasanya masing-masing dan memiliki karakteristik teologis lainnya. Aksara tersebut juga memiliki tempatnya masing-masing di bhuana alit di bagian-bagian tubuh (organ dalam).

Aksara Sa ditempatkan di jantung, Ba di hati, Ta di lambung, A di empedu, I di dasar hati, $\mathrm{Na}$ di paru-paru, Ma di usu halus, Si di ginjal, Wa di kerongkongan dan Ya ditempatkan di ujung hati (Yudiantara, 2016: 209-210; Anonim, 1996a). Sejumlah aksara inilah kemudian diputar penempatannya dalam organ dalam, saat praktik yoga dengan asana 'sikap badan' tertentu. Teknik khusus pelatihannya juga dikombinasikan dengan olah nafas (pranayama) dan aspek astangga yoga lainnya. Selengkapnya delapan tahapan praktik yoga tersebut, yakni: yama, niyama, asana, pranayama, pratyahara, dharana, dhyana, dan semadhi (Tim Penyusun, 2012: 24).

\subsection{Pengertian Bade sebagai Arsitektur Ban- gunan Kematian}

Kata bade berasal dari kata wadah karena huruf $\mathrm{p}, \mathrm{b}$, dan w adalah satu warga, yaitu samasama aksara labial. Dengan demikian istilah wadah dapat berubah menjadi kata badah, dari kata badah menjadi kata bada yang artinya tempat/ ruangan, sehingga ada istilah bada saang 'tempat kayu bakar, bada celeng 'kandang babi', bada motor 'garase' dan lain-lain. Kata bada kemudian menjadi bade dalam pengertian tempat menaruh jenazah sebagai salah satu sarana dalam upacara pengabenan (Wiana, 2004: 73).

Kata bade diartikan juga sebagai tempat besar dan tinggi untuk mengusung jenazah yang akan dibakar di kuburan (Anandakusuma, 1986: 14). Wadah atau bade sebagai salah satu pemereman 'peraduan akhir' secara arsitektural adalah suatu jenis/bentuk bangunan tradisional Bali yang bersifat sementara dan ringan berbentuk bebaturan dan pepalihan, di atasnya berdiri balaibalai, dirancang khusus untuk tempat jenazah pada waktu akan diusung dari rumah duka menuju ke kuburan (Sulistyawati, 2008: 102).

Arsitektur bade tersusun atas pepalihan (bagian-bagian) yang menyusun bagian badan dan atapnya. Bentuknya bervariasi ada yang tidak bertumpang dikenal dengan sebutan wadah dan yang atapnya bertumpang disebut bade, bahkan ada yang tidak beratap (terbuka) yang disebut padma.

Ketentuan jumlah tumpang bade ditetapkan dalam masing-masing prasasti atau babad klan/ warga bersangkutan sebagai sebuah penugrahan raja pada masa kerajaan dahulu, yang masih mentradisi sampai sekarang. Tingkatan atap tumpang ini menunjukkan status sosial yang bersangkutan di masyarakat adat atau jabatan yang pernah dipangku semasa hidupnya. Misalnya untuk raja berhak memakai tumpang 11, para menteri tumpang 9, para patih tumpang 7, demikian pula warga Pasek memakai tumpang 7, mengingatkan tujuh orang leluhurnya adalah para pandita agung di masa silam. Klan yang lain memakai tumpang 5 atau 3 (Titib, 2001: 119-120).

\subsection{Bentuk Arsitektur Bade}

Bentuk bangunan untuk upacara ngaben dipengaruhi oleh kedudukan seseorang dalam strata sosial tradisional di masyarakat Bali, yakni kelompok tri wangsa (brahmana, ksatria, dan wesia), dan kelompok jaba wangsa.

\section{a. Arsitektur Bade Kaum Brahmana}

Kaum Brahmana dalam kontek ini dipahami sebagai siapa saja yang sudah melakukan proses penyucian diri baik ekajati maupun dwijati atau pinandita dan pandita yakni kaum rohaniawan Hindu. Arsitektur bade untuk seorang rohaniawan berbentuk padmasana atau padmasari. Penggunaan bentuk bangunan mirip pelinggih 'bangunan suci' di tempat suci (pura dan pemerajan), hal ini dimungkinkan karena diyakini pendeta adalah Sang Adi Guru Loka atau guru pengajian bagi umat yang tugasnya mengabdi pada bidang keagamaan. 
Bagi para orang suci ini, dalam upacara pengabenan-nya menggunakan arsitektur bade berbentuk padma. Para Pandita 'pendeta' berhak memakai bentuk Padmasana dan Padmanglayang yakni lengkap menggunakan bedawangnala, sedangkan bagi Pinandita 'pemangku' hanya berhak menggunakan bentuk Padmasari tanpa bedawangnala.

Bentuk tempat persemayaman orang suci ini disinggung dalam lontar Asta Kosala Kosali lembar no 56/b (Anonim, 1996b: 54), sebagai berikut:

"Iti wastan wadhah mautama, nga. Padmasana,
Padmasari, Padmanglayang. Padmasana,
malengkyang maileh, macandi raras,
padmanglayang, nga."
Artinya:
Inilah nama wadah atau bade yang utama.
Padmasana, Padmasari dan Padmanglayang.
Padmasana malengkyang keliling.
Padmanglayang menggunakan hiasan candi
raras.

\section{b. Arsitektur Bade Kaum Kesatria}

Arsitektur bade warga Ksatria dibagi menjadi dua yakni: arsitektur bade untuk raja penguasa tunggal dan raja di bawah penguasa tunggal.

\section{(1). Arsitektur Bade Raja Penguasa Tunggal (Raja di Raja)}

Pemereman 'persemayaman' untuk raja-raja mengambil bentuk bade yang dilengkapi dengan naga banda. Bade menggunakan atap bertingkat sebagai lambang alam semesta dengan berbagai puncak gunung yang disimbolkan melalui tumpang. Jumlah tingkat biasanya ganjil, yakni dari tertinggi sampai terendah adalah 11, 9, 7, 5, dan 3 yang sering disebut megunung solas, megunung sia, megunung pitu, megunung lima, megunung telu. Ini merupakan simbol agar roh orang yang diaben segera mencapai alam kedewataan yang diyakini berada di puncak gunung tertinggi (Titib, 200: 119-120).
Besarnya bilangan tumpang juga merupakan perlambang tingkat kekuasaan leluhur seseorang dimasa lampau. Makin besar kekuasaannya makin tinggi tumpang yang boleh dipakai sesuai anugerah raja tertinggi. Disamping itu, jumlah tumpang juga menjadi lambang lapisan alam semesta dan dewa-dewa penguasa segala penjuru mata angin (astadikpalaka).

Perbedaan bentuk bade bagi raja dan bawahannya dapat dilihat dari beberapa hal yakni ornamen, keberadaan nagabanda dan jumlah tumpang. Bade untuk raja memakai struktur palih lima, selengkapnya dari atas ke bawah adalah: palih sari, palih taman, palih sancak, palih karas, palih batur, dan tumpang atapnya sebanyak sebelas. Tingkat sebelas melambangkan bahwa raja adalah pusat dari segala kekuasaan dan memiliki kekuasaan mutlak seluruh penjuru mata angin kerajaan termasuk langit dan bumi. Hal ini menyamai kekuasaan dewa tertinggi yaitu dewa Siwa. Keyakinan ini berkaitan dengan konsep dewa raja yang menganggap raja sebagai penjelmaan dewa (Sulistyawati, 2008: 107).

\section{(2). Arsitektur Bade Raja di Bawah Penguasa Tunggal}

Bade untuk raja-raja lain setingkat di bawah raja penguasa tunggal adalah bertingkat sembilan (megunung sia). Jumlah tumpang sembilan juga dipakai oleh sanak keluarga raja penguasa tunggal itu sendiri. Ini melambangkan bahwa luas kekuasaannya sampai ke sembilan penjuru mata angin dari wilayah kerajaan seperti halnya kekuasaan para dewata (Sulistyawati, 2008: 107; Suyoga, 2014: ).

\section{c. Arsitektur Bade Warga Wesia}

Arsitektur bade untuk golongan wesia atau keluarga yang leluhurnya pernah menjadi punggawa atau pejabat yang sederajat, mengambil wujud wadah dengan dasar bade, yaitu wadah yang dasarnya mempergunakan badawangnala atau ornamen saja (Sulistyawati, 2008: 110; Suyoga, 2014: ). 


\section{d. Arsitektur Bade Warga Jaba}

Ketiga klasifikasi di atas adalah untuk warga tri wangsa yang diistilahkan tinggal di jeroan (dalam), sedangkan kelompok warga lainnya yang tinggal di luar jeroan atau di luar tri wangsa disebut jaba wangsa. Arsitektur bade untuk warga jaba (masyarakat kebanyakan) pada umumnya mengambil wujud wadah dengan dasar babogeman, yang sering juga disebut bale-balean. Bangunan temporer ini sangat sederhana, tidak memakai bhoma dan paksi. Demikian pula ragam hiasnya hanya dari bahan kertas tanpa memakai kapas. Sanan 'pemikulnya' hanya satu gulung atau lapis ke arah muka-belakang ataupun ke samping (Wikarman, 2002:106).

Walaupun bentuk wadah diperbolehkan, namun banyak masyarakat golongan jaba lebih suka hanya memakai wadah berbentuk joli dan pepaga. Kemungkinan hal ini disebabkan oleh keberadaan ekonomi kaum jaba dahulunya kebanyakan berada di bawah garis kemiskinan. Namun meskipun dewasa ini keberadaan ekonomi mereka sudah meningkat bahkan ada yang hampir menyamai atau bahkan melampaui golongan tri wangsa, masih ada yang tetap patuh memilih bentuk joli dan pepaga (Jro Mangku Undagi I Nyoman Artana, wawancara 2018).

\section{DISKUSI}

Dasa Aksara yang dipahami sebagai sepuluh huruf suci, merupakan penjabaran dan ajaran terstruktur dari Ilmu Kebathinan Bali yang baik secara psikologis maupun secara metafisik sangat besar manfaatnya. Dasa Aksara teraplikasi dalam ranah makrokosmik maupun mikrokosmik. Secara makrokosmos pengejawantahan Dasa Aksara dapat disepadankan dengan pengideran dalam konsep Pengider-Ideran Dewata Nawa Sang.

Pangider-ider berasal dari kata ider yang artinya berputar. Putaran purwa-daksina ini searah putaran jarum jam, mulai dari arah Timur ke Selatan dan kembali ke tengah. Adapun pangiderider merupakan refleksi dari Dewata Nawasanga yaitu sembilan manifestasi Siwa dalam sembilan arah mata angin. Dalam lontar Usana Bali lembar 1b, yang dikutip Manuaba, (2006: 75), disebutkan sebagai berikut:

"Iti teges ing bhuwana jagat, cinaritaken tingkahing Dewata Nawasanga munggwing bhuwana kabeh. Purwantu Iswara Dewa, Aghneyantu Mahesora, Daksina Bhatara Brahma, Neriti Rudra Dewata, Pascimantu Mahadewa, Wayabya Sangkara sthana, Uttara Wisnu Dewata, Hairsanya Sambhu Dewata, Madya Siwa Dewa”.

Artinya:

"Ini adalah keadaan di dunia, dikisahkan Dewata Nawasanga dan kedudukannya di dunia. Di Timur Dewa Iswara, di Tenggara Mahesora, di Selatan Bhatara Brahma, di Barat Daya Rudra Dewata, di Barat Mahadewa, di Barat Laut adalah sthana Sangkara, di Utara Wisnu Dewata, di Timur Laut Sambhu Dewata dan di Tengah Dewa Siwa”.

Gunadha (1989:82) mengutip pernyataan Wojowasito (1954:150), menyatakan Dewata Nawasanga terdiri dari kata dewata yang berarti para dewa, kata nawa berarti sembilan dan sanga berarti tinggi, ke atas, atau yang diangkat tinggi dalam Dewata Nawasanga merupakan sembilan dewata tertinggi sebagai manifestasi Sang Hyang Widhi sesuai dengan fungsi yang dinyatakan dalam posisi/letak pada sembilan penjuru. Dewata Nawasanga terdiri dari Panca Dewata, yaitu Brahma, Wisnu, Siwa, Iswara, dan Mahadewa, ditambah Maheswara, Rudra, Sangkara, dan Sambu.

Kesembilan dewa tersebut dilambangkan dengan wijaksara: Sa, Ba, Ta, A, I, Na, Ma, Si, Wa, dan Ya. Sa adalah Sadyojata atau Iswara di Timur, Ba adalah Bhamadewa atau Brahma di Selatan, A adalah Aghora atau Wisnu di Utara, Ta adalah Tadpurusa atau Mahadewa di Barat, I adalah Isana, yaitu Siwa di Tengah, selanjutnya $\mathrm{Na}$ adalah Maheswara di Tenggara, Ma adalah Rudra di Barat Daya, Si adalah Sangkara di Barat Laut, 
Wa adalah Sambu di Timur Laut, dan Ya adalah Siwa di Tengah.

Titib (2001: 383) menyatakan dewata penguasa kiblat mata angin, disebut astadikpalaka adalah berdasarkan Siwatattwa (Saiwa Siddhanta). Informasi ini juga dapat dijumpai dalam puja Astamahabhaya (Hooykaas, 1971:65 dalam Titib 2001:384), yaitu penguasa kiblat di Timur, dewa Iswara membawa senjata bajra, Tenggara Maheswara membawa senjata dhupa, Selatan Brahma membawa senjata gada, Barat Daya Rudra membawa senjata danda, Barat Mahadewa membawa senjata nagapasa, Barat Laut Sangkara membawa senjata angkus, Utara Wisnu membawa senjata cakra, dan Timur Laut Sambhu membawa senjata trisula. Di Tengah dewa Siwa membawa senjata padma.

Sepuluh huruf suci tersebut diyakini sebagai urip bhuana 'jiwa alam' yang letaknya di sepuluh penjuru alam semesta termasuk di tengah, kesepuluh huruf itu adalah:

- Huruf suci Sa, letaknya di Timur, Dewanya Iswara dan warnanya putih.

- Huruf suci Ba, letaknya di Selatan, Dewanya Brahma dan warnanya merah.

- Huruf suci Ta, letaknya di Barat, Dewanya Mahadewa dan warnanya kuning.

- Huruf suci A, letaknya di Utara, Dewanya Wisnu dan warnanya hitam.

- Huruf suci I, letaknya di Tengah, Dewanya Ciwa dan warnanya campuran (panca warna/brumbun).

- Huruf suci Na, letaknya di Tenggara, Dewanya Mahesora dan warnanya merah muda (dadu).

- Huruf suci Ma, letaknya di Barat Daya, Dewanya Rudra dan warnanya jingga.

- Huruf suci Si, letaknya di Barat Laut, Dewanya Sangkara dan warnanya hijau.

- Huruf suci Wa, letaknya di Timur Laut,
Dewanya Sambu dan warnanya biru.

- Dan yang terakhir adalah Huruf suci Ya, letaknya di Tengah Atas, Dewanya Ciwa dan warnanya juga campuran (panca warna/brumbun). Sedangkan panunggalan sepuluh huruf itu menjadi satu lambang aksara suci bagi umat Hindu, yaitu Omkara (huruf suci Sang Hyang Widhi Wasa/Tuhan Yang Maha Esa).

Kuasa pengetahuan kesepuluh huruf suci dan huruf suci Omkara pada arsitektur bade diinterpretasikan pada tumpang bade. Hal ini merujuk pemikiran Foucault yang memahami kekuasaan sebagai strategi. Strategi kekuasaan sebagai yang melekat pada kehendak untuk mengetahui; selanjutnya melalui wacana, kehendak untuk mengetahui terumus dalam pengetahuan. Bahasa menjadi alat untuk mengartikulasikan kekuasaan pada saat kekeuasaan haru smengambil bentuk pengetahuan. Pengejawantahan relasi kuasa pengetahun tersebut, dapat diuraikan sebagai berikut:

- $\quad$ Bade beratap sebelas adalah lambang dari sebelas huruf suci, yaitu sepuluh huruf suci ( $\mathrm{Sa}, \mathrm{Ba}, \mathrm{Ta}, \mathrm{A}, \mathrm{I}, \mathrm{Na}, \mathrm{Ma}, \mathrm{Si}$, Wa, Ya) ditambah huruf suci Omkara sebagai lambang Eka Dasa Dewata.

- $\quad$ Bade beratap sembilan adalam lambang 8 huruf di seluruh penjuru ( $\mathrm{Sa}, \mathrm{Ba}, \mathrm{Ta}, \mathrm{A}, \mathrm{Na}$, $\mathrm{Ma}, \mathrm{Si}, \mathrm{Wa})$ ditambah huruf suci Omkara di tengah, huruf 9 itu lambang Dewata Nawa Sanga.

- $\quad$ Bade beratap tujuh adalah lambang 4 huruf di penjuru Timur, Selatan, Barat dan Utara (Sa, Ba, Ta, A) ditambah 3 huruf tengah (I, Omkara, Ya) 7 huruf ini lambang Sapta Dewata atau Sapta Rsi.

- Bade beratap lima adalah simbol dari lima huruf yaitu penjuru Timur, Selatan, Barat, Utara, (Sa, Ba, Ta, A) ditambah satu huruf Omkara di tengah, lima huruf ini lambang Panca Dewata. 
- $\quad$ Bade beratap tiga adalah simbol dari tiga huruf di tengah (I, Omkara, Ya) merupakan lambang Tri Purusa yaitu Parama Siwa, Sada Siwa dan Siwa.

- Bade beratap dua adalah simbol dari dua huruf di tengah (I, Ya) adalah lambang dari Purusa dan Pradhana (Bapak-Ibu).

- Bade beratap satu adalah simbol dari penunggalan kesepuluh huruf suci itu, yaitu Om atau Omkara sebagai perlambang Sang Hyang Tunggal (Sang Hyang Widhi Wasa atau Tuhan Yang Maha Esa).

Relasi kuasa pengetahuan dalam konsep pengider-ider terkait dengan arsitektur bade, dapat dilihat dari jumlah tumpang atap bade yang sangat terkait dengan besar kecil atau luasnya kekuasaan mendiang pada masa hidupnya. Sulistyawati (2008: 107), menyatakan bahwa tingkat atap sebelas melambangkan bahwa raja adalah pusat dari segala kekuasaan dan memiliki kekuasaan mutlak seluruh penjuru mata angin kerajaan termasuk langit dan bumi. Hal ini menyamai kekuasaan dewa tertinggi yaitu Dewa Siwa. Pengetahuan tentang kultus Dewa Siwa sebagai dewa tertinggi, ditangkap dan diartikulasikan menjadi pusat kekuasaan raja di raja dengan pemakaian tumpang sebelas.

Jumlah tumpang sembilan melambangkan bahwa luas kekuasaannya sampai ke sembilan penjuru mata angin dari wilayah kerajaan, seperti halnya kekuasaan para dewata. Bilangan tujuh melambangkan kekuasaan atas Utara-Selatan, Timur-Barat, dan Bawah-Tengah-Atas. Bilangan lima melambangkan kekuasaan atas UtaraSelatan, Timur-Barat dan Tengah. Tumpang tiga melambangkan kekuasaan dewata atas tiga dunia yaitu: alam bawah, tengah dan atas.

Kekuasaan seseorang (raja di raja, raja bawahan, keluarga raja, mantri, patih, prebekel, dan para tokoh masyarakat lainnya) terhadap luas wilayah tertentu di dunia, diinterpretasikan atas penguasaan arah penjuru mata angin.
Kekuasaan atas arah mata angin ini kemudian ditransformasikan pada tingkatan atap bangunan bade. Proses transformasi ini juga tidak dapat dipisahkan dengan simbolisasi pengelukunan dasa aksara (penyatuan sepuluh huruf suci) sebagai jiwa 'urip' dari bade atau lapisan alam semesta yang dilambangkan dengan tumpang atap bade tersebut.

Relasi kuasa pengetahuan melalui pemakaian tumpang atap bade yang merupakan penglukunan dasa aksara 'penyatuan sepuluh huruf suci', mengandung harapan agar roh mendiang yang diupacarai menuju ke alam kedewataan atau mencapai puncak astangga yoga, yakni maha semadhi; sesuai dengan luasnya kekuasaan pada masa hidupnya, seperti kekuasaan dewata atas arah mata angin tersebut.

Berbeda halnya pada arsitektur bade persemayaman orang suci Hindu. Persemayamannya berbentuk padma tanpa atap yang merupakan simbol windu (kosong). Atap sebagai simbol kekuasaan tidak lagi dipergunakan, karena para orang suci sudah tidak lagi diikat oleh keduniawian termasuk kekuasaan.

Secara semiotik, arsitektur bade adalah sebuah simbol. Sebagai sebuah simbol, bade mengarahkan pada sesuatu yang transenden dan imanen. Sebagai simbol transenden, bade merupakan simbolisasi umat Hindu untuk menghubungkan dirinya dengan Yang Tunggal, Yang Tidak Terbayangkan, atau Achintya 'tidak terpikirkan', sebuah esensi dari praktik yoga; karena itu, pada ulon 'puncak dinding' bade dan wadah diberi gambar Achintya.

Cohen (1974 dalam Triguna, 2000: 24), berpendapat bahwa simbol adalah sesuatu yang obyektif yang pada awalnya merupakan reaksi spontan individu berdasarkan pengalaman subyektif spesifik, dan mencapai obyektivasi dalam interaksi sosial. Hal yang semula bersifat individu menjadi obyektif-kolektif. Hal ini dalam bahasa Foucault dipahami sebagai kuasa pengetahuan. Kuasa pengetahuan itu tersebar, tidak dimiliki 
seseorang semata. Ia dapat ditangkap oleh siapa saja dan dapat dijadikan kuasa oleh orang-orang yang memiliki kuasa untuk "berbicara" (praktik profesi). Foucault menyatakan kekuasaan sebagai stategi kompleks dalam suatu masyarakat dengan perlengkapan, manuver, teknik, dan mekanisme tertentu (Haryatmoko, 2016: 15).

Dalam kaitan arsitektur bade sebagai simbol, mencatat, bahwa para kawi sastra yang juga seorang undagi, menuangkan hasil kontemplasi dalam yoga beliau yang mendalam "dharanadhyana-semadhi” menuju yang transenden, telah menghasilkan sebuah wujud bangunan persemayaman sebagai simbol yang transenden. Wacana primer relasi kuasa pengetahuan tersebut kemudian dituangkan dalam wacana sekunder berupa panduan desain arsitektur wadah dan bade, dan sejumlah wacana tersier dalam praktik ritualnya di tengah masyarakat.

Relasi kuasa pengetahuan dalam wacana sekunder ini, ditangkap oleh aktor-aktor intelektual organik, seperti raja di raja, rohaniwan, undagi dan tokoh masyarakat lainnya yang memiliki kuasa untuk berbicara atas nama pengetahuan tersebut. Para aktor intelektual ini menangkap dan mengembangkan relasi kuasa pengetahuan tersebut sebagai wacana sekunder, yang kemudian berkembang lagi menjadi wacana tersier dan seterusnya.

Bade juga merupakan simbol yang bersifat imanen, karena masyarakat Hindu Bali meyakini bahwa bade adalah tempat atau sebagai simbol kendaraan roh menuju Yang Tunggal atau Sang Hyang Widhi atau Paramasiwa. Mereka berinteraksi secara simbolik dalam kancah masyarakat dalam praktik ritus keagamaan.

Dengan demikian, arsitektur bade dengan bentuknya yang bervariasi, ada disebut wadah yang tidak bertumpang; yang atapnya bertumpang disebut bade, dan yang tidak beratap (terbuka) disebut padma. Varian atap inilah wujud relasi kuasa pengetahuan, hasil kontemplasi mendalam "yoga" penglukunan dasa aksara. Jadi, dalam bahasa Foucault dapat dinyatakan, pengetahuan tentang penglukunan dasa aksara ditangkap oleh undagi bade untuk dikembangkan sebagai kuasa dalam praktik profesinya. Praktik kuasa pengetahuan ini berlaku di ranah masyarakat Bali yang tubuhnya telah disiplin, patuh, dan berguna dalam menjalankan praktik kultural berupa seremonial kematian (ngaben).

\subsection{Makna Sosial}

Kuasa pengetahuan dalam yoga penglukunan dasa aksara dapat dimaknai oleh seorang undagi bade, tidak hanya terbatas pada praktik mewujudkan benda budaya atau artefak berbentuk bangunan wadah atau bade semata, namun relasinya masih jauh dapat berjalan menuju ke kedalaman olah bathin. Internalisasi yoga penglukunan dasa aksara menjadi proses pelatihan tubuh yang tiada henti bagi seorang undagi. Praktik disiplin olah tubuh (olah badan/olah raga) dan olah bathin melalui tahapan astangga yoga mutlak dilakoni oleh seorang undagi dalam praktik profesinya. Lontar Asta Kosala Kosali dan juga lontar Indik Mekarya Bade dengan jelas menegaskan hal ini. Jika seseorang melakukan praktik bangun membangun/ pertukangan sebagai undagi 'arsitek', maka ia hendaknya mempertanggungjawabkan hasil karyanya baik secara sekala 'riil' dan juga niskala 'gaib'. Ia mempersembahkan karyanya kepada mendiang, keluarga mendiang, masyarakat, dan kepada Bhagawan Wiwakarma sebagai perpanjangan tangan dari Dewa Siwa.

Dengan demikian praktik disiplin tubuh melalui yoga penglukunan dasa aksara atau dalam bahasa Foucault disebut kuasa disiplin (Haryatmoko, 2016: 15). Proses kerja kuasa disiplin pada seorang undagi akan membuat dirinya taat, patuh dan berguna dalam praktik profesinya. Pengetahuan dibalik penglukunan dasa aksara, ditangkap dan dijadikannya kuasa dalam praktik profesinya. Pemahamannya terhadap 
esensi bija aksara dan proses penglukunannya 'penyatuan aksara suci' tersebut, menjadikan karya arsitektur wadah/bade yang dirancangnya mampu mewakili relasi kuasa pengetahuan yang bekerja di dalamnya. Kuasa mendiang semasa hidupnya mampu diejawantahkan pada perwujudan secara arsitektural.

Bentuk pepalihan pengawak 'bagian badan' wadah dan bade', maupun jumlah atap wadah/ bade yang menjadi simbolik kuasa mendiang semasa hidup atau kuasa leluhurnya terdahulu di era kerajaan, yang merupakan hasil pembacaan mendalam praktik yoga penglukunan dasa aksara. Masyarakat Bali mampu berinteraksi dengan kapital simbolik yang diwujudkan secara arsitektural tersebut. Kapital simbolik dalam pemikiran Bourdieu ini merupakan bentuk modal simbolik yang dimiliki seseorang karena kebangsawanan, gelar, jabatan, kepemimpinan, dan nama besar keluarga. Kapital simbolik akan menghasilkan kekuasaan simbolik. Maka, kekuasaan simbolik membutuhkan simbol-simbol kekuasaan tersebut (Haryatmoko, 2016: 45). Kapital simbolik seseorang terkait arsitektur bade ini tertuang dalam wacana babad soroh, prasasti, pamancangah, bhisama klan, atau bentuk transkrip keluarga besar lainnya.

Ketentuan ini diturunkan dari generasi ke generasi sebagai sebuah anugrah Dalem Klungkung "Raja di Raja Bali" era Bali Madya/ Bali Majapahit (1343 M - awal abad ke19). Kapital simbolik hasil kontemplasi yoga penglukunan dasa aksara ini sudah berkontestasi sekitar lima abad dalam kehidupan sosio-religius masyarakat Bali. Praktik budaya ini, menunjukkan bahwa kuasa pengetahuan yoga penglukunan dasa aksara tersebut masih fungsional dalam struktur tradisional masyarakat Bali yang kini telah memasuki era pascamodern dengan berbagai tekanan globalisasi dan pergulatan kuasa era kontemporer.
Foucault menyatakan kuasa pengetahuan itu tidak dimiliki seseorang tapi tersebar dan ada dimana-mana (Haryatmoko 2016: 15). Hal ini menekankan dalam relasi kuasa pengetahuan, pengetahuan dapat ditangkap oleh siapa saja untuk menjadikannya kuasa dalam sebuah ranah tertentu. Fakta empiris menunjukkan pengetahuan tersebut rupanya sudah ditangkap oleh kaum kapitalis untuk menjadikannya kuasa dalam ranah komersial. Proses komodifikasi arsitektur bade dapat dijumpai dalam berbagai sentra pengerajin bade yang tersebar di hampir seluruh wilayah Bali. Pola distribusi dan konsumsinyapun sudah tersebar tidak saja di Bali dan luar Bali terkait kebutuhan ritual kematian, namun juga telah berkembang untuk kelengkapan museum baik di Bali maupun di luar negeri, seperti untuk museum Yadnya di Mengwi, museum budaya di Amerika, dan museum etnis di Jerman (Suyoga, 2014: 138139).

\subsection{Makna Internalisasi Personal}

Relasi kuasa pengetahuan penglukunan dasa aksara juga menjadi latihan yoga keseharian seorang undagi dalam upaya akhirnya untuk memahami kesejatian Sang Diri Sejati "Siwa". Proses internalisasi praktik yoga ini menjadi mutlak bagi seorang undagi dalam upaya pengolahan energi semesta dalam alur pemahaman adanya kesamaan unsur makrokosmik dengan mikrokosmik.

Seorang undagi disamping mampu dan trampil secara teknis arsitektural, juga dituntut mumpuni secara olah bathin, dan salah satu caranya melalui praktik disiplin tubuh melalui yoga penglukunan dasa aksara. Peletakan keseluruhan bija aksara dalam organ dalam dirinya dan proses penyatuan, pemutaran tahap demi tahap energi yang mulai aktif guna mencapai keseimbangan dan fokus fungsionalnya. Secara detail praktik ini dapat 
dipelajari pada tuntunan lontar penglukunan dasa aksara, tentunya sangat disarankan melalui tuntunan guru spiritual yang memahaminya.

Undagi pada keseluruhan proses praktik profesinya diharapkan mampu mencapai kesadaran keduniawian dan hakekat kesejatian yang dilatihnya melalui pendekatan tubuh fisiknya. Hasil akhir tentunya sebuah kesejahteraan (sehat badani) dan kebahagiaan (sehat bathin) sepanjang praktik profesinya sebagai undagi. Inilah sebenarnya hakekat internalisasi personal dari kata swagina-swadharma. Profesional dalam profesi diri secara sekala-niskala.

\section{PENUTUP}

Arsitektur bade dengan bentuknya yang bervariasi, ada disebut wadah yang tidak bertumpang, dan yang atapnya bertumpang disebut bade, bahkan ada yang tidak beratap (terbuka) disebut padma. Varian atap ini merupakan relasi kuasa pengetahuan, hasil kontemplasi mendalam "yoga" penglukunan dasa aksara. Jadi, dalam bahasa Foucault dapat dinyatakan, pengetahuan tentang penglukunan dasa aksara ditangkap oleh undagi bade untuk dikembangkan sebagai kuasa dalam praktik profesinya. Praktik kuasa pengetahuan ini berlaku di ranah masyarakat Bali yang tubuhnya telah disiplin, taat patuh, dan berguna dalam menjalankan praktik kultural berupa seremonial kematian (ngaben).

Seorang undagi disamping mampu dan trampil secara teknis arsitektural, juga dituntut mumpuni secara olah bathin, dan salah satu caranya adalah praktik disiplin tubuh melalui yoga penglukunan dasa aksara. Peletakan keseluruhan bija aksara dalam organ dalam dirinya dan proses penyatuan, pemutaran tahap demi tahap energi yang mulai aktif guna mencapai keseimbangan dan fokus fungsionalnya. Relasi kuasa pengetahuan secara internal personal inilah dipahami sebagai kuasa disiplin dalam bahasa Foucault. Disiplin pelatihan yoga seorang undagi bade dalam proses pencarian dirinya yang sejati (Siwa) di jalan Tantra.

\section{DAFTAR PUSTAKA}

Anonim. 1996a. Dasa Aksara. Alih Aksara Lontar. Denpasar: Kantor Dokumentasi Budaya Bali. Pemerintah Propinsi Bali. . 1996b. Asta Kosala Kosali. Alih Aksara Lontar. Denpasar: Kantor Dokumentasi Budaya Bali. Pemesrintah Propinsi Bali.

Gunadha, Ida Bagus.1989. Pura Agung Jagatnatha. Tidak dipublikasikan. Institut Hindu Dharma Indonesia.

Haryatmoko. 2016. Membongkar Rezim Kepastian Pemikiran Kritis Post - Strukturalis. Yogyakarta: PT. Kanisius.

Manuaba, Ida Bagus Gde Kartika. 2006. "Padmasana dari Konsepsi Menuju Bentuk". Tesis (tidak diterbitkan). Denpasar: Universitas Hindu Indonesia Denpasar.

Sulistyawati. 2008. Arsitektur Orang Mati di Bali. Pustaka Arsitektur Bali. Denpasar: Ikatan Arsitek Indonesia Daerah Bali.

Suyoga, I Putu Gede. 2014. Arsitektur Bade, Transformasi Konsep Menuju Bentuk. Gianyar: Kryasta Guna.

Tim Penyusun. 2012. Yoga. Denpasar: Dirjen Bimas Hindu Kementrian Agama RI.

Titib, Made. 2001. Teologi dan Simbol-Simbol dalam Agama Hindu. Surabaya: Badan Litbang Parisada Hindu Dharma Indonesia Pusat bekerjasam dengan Penerbit Paramita.

Triguna, Ida Bagus Gde Yudha. 2000. Teori Tentang Simbol. Denpasar: Widya Dharma.

Wiana, I Ketut. 2004. Makna Upacara Yadnya Dalam Agama Hindu II. Surabaya: Paramita. Wikarman, Singgih. 2002. Ngaben (Upacara dari 
Tingkat Sederhana sampai Utama). Surabaya: Paramita.

Yudiantara, Putu. 2016. Sakti Sidhi Ngucap. Eksplorasi dan Aplikasi Ilmu Leak, Kanda Pat, dan Dasa Aksara untuk Orang Modern. Denpasar: Bali Wisdom.com. 